\title{
Summary of the Intercomparison of the Force Standard Machines of the National Institute of Standards and Technology, USA, and the Physikalisch-Technische Bundesanstalt, Germany
}

Volume 96

Number 5

September-October 1991

Simone L. Yaniv

National Institute of Standards and Technology, Gaithersburg, MD 20899 USA

and

\section{A. Sawla and M. Peters \\ Physikalisch-Technische Bundesanstalt, Germany}

A comparison of force mcasurcments performed at the National Institute of Standards and Technology, USA, and at the Physikalisch-Technische Bundcsanstalt, Germany is reported. The focus of the study was the intercomparison of the forces realized by the two Institutes rather than the measurement process. The transfer standards used in the comparison consisted of force transducers and associated readout instrumentation. The results of the intercomparison reveal that over a range of $50 \mathrm{kN}$ to 4.5 $\mathrm{MN}$, the forccs realized at NIST and at
PTB compare favorably. For forces up to $900 \mathrm{kN}$ the agreement is within \pm 40 ppm; above $900 \mathrm{kN}$ the agreement is within $\pm 100 \mathrm{ppm}$.

Key words: deadweight machines; force mcasuremcnts; force standards; force transducers.

Accepted: July 10, 1991

\section{Introduction}

This paper summarizes the results of a comparison of force measurements performed at the $\mathrm{Na}$ tional Institute of Standards and Technology (NIST), USA, and at the Physikalisch-Technische Bundesanstalt (PTB), Germany. A detailed description of the study can be found in Ref. [1].

The objective of the study was to determine the comparability of the forces realized by the two Institutes over a range of $50 \mathrm{kN}$ to $4.5 \mathrm{MN}$, so that the results of force transducer calibrations performed at one Institute would be more readily accepted by the other. The need for the comparison was acute as there are significant differences in the force machines used by the two Institutes. At NIST the forces applied are generated by deadweights over the entire range included in the study. At PTB forces up to $1 \mathrm{MN}$ are applied by deadweights but higher forces are generated by means of a hydraulic force-multiplication system.
The overall program for the intercomparison was developed jointly by NIST and PTB. The protocol used during the measurements was developed by PTB. Planning for the program began late in 1988. Initial measurements of all the force transducers involved in the comparison were carried out first at PTB in September 1989. These initial measurements were followed by a set of similar measurements at NIST in October 1989. To verify the stability of the force transducers used during the comparison, a final set of measurements was obtained at PTB in November 1989.

\section{Force Standard Machines}

The force standard machines of both Institutes have been described in details in Refs. [1-4]. Accordingly, only a brief description of the machines is given here. 


\subsection{The NIST Deadweight Force Standard Machines}

Only the three largest NIST deadweight machines were included in the intercomparison. These machines, known as the $1 \mathrm{Mlbf}$, the $300 \mathrm{klbf}$ and the $112 \mathrm{klbf}$ machines have been described in Refs. [1,2]. The most important features of these machines are summarized in Table 1 . Drawings of the two largest machines are given in Figs. 1 and 2, and a photograph of the $112 \mathrm{klbf}$ machine is given in Fig. 3.

The estimated total uncertainty of the vertical component of force applied by any weight is 0.002 percent. If corrections are made for the actual air density during a calibration and for the actual adjusted mass of each weight, the uncertainty of the applied force can be reduced to 0.001 percent.

The schematic drawing in Fig. 4 illustrates the operating principles of the deadweight machines. Each of the three machines has a stack of large weights, represented by the lower stack of larger weights in Fig. 4. Only the $112 \mathrm{klbf}$ machine also has a second stack of smaller weights that are operated by screw jacks. To apply a deadweight load, the hydraulic jack raises the lifting frame and the loading frame, acting through the device being calibrated in either compression or tension.

As the loading frame is raised, the large weights are picked up in sequence, beginning with the top weight of the stack. In the $112 \mathrm{klbf}$ machine, the smaller weights are lowered onto the loading frame

Table 1. Charactcristics of the three largest NIST deadwcight machines

\begin{tabular}{lccc}
\hline \hline $\begin{array}{l}\text { Capacity: (nominal) } \\
\text { kN } \\
\text { (klbf) }\end{array}$ & 4448 & 1334 & 498 \\
& $(1000)$ & $(300)$ & $(112)$ \\
$\begin{array}{l}\text { Minimum load: (nominal) } \\
\text { kN } \\
\text { (klbf) }\end{array}$ & 222 & 44 & 13 \\
Minimum increment: (nominal) & $(50)$ & $(10)$ & $(3)$ \\
$\quad$ kN & & & \\
$\quad(k l b f)$ & 222 & 44 & 4.4 \\
& $(50)$ & $(10)$ & $(1)$ \\
$\begin{array}{l}\text { Time to capacity, s } \\
\text { Comprcssion setup space: }\end{array}$ & 345 & 292 & 274 \\
$\quad$ Vertical, m & & & \\
$\quad$ Horizontal, m & 1.98 & 1.65 & 1.02 \\
& 0.86 & 0.91 & 0.71 \\
Tension sctup space: & & & \\
$\quad$ Vertical, m \\
$\quad$ Horizontal, m & 4.45 & 2.49 & 2.16 \\
\hline
\end{tabular}

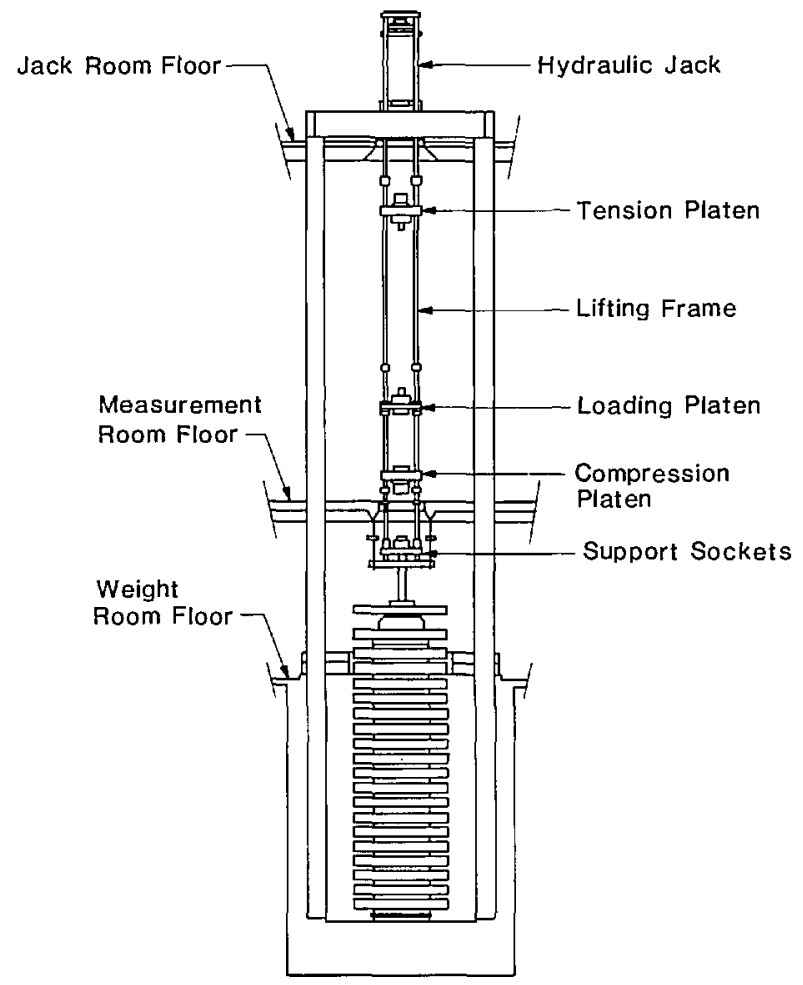

Figure 1. The NIST 1 Mlbf deadweight machine.

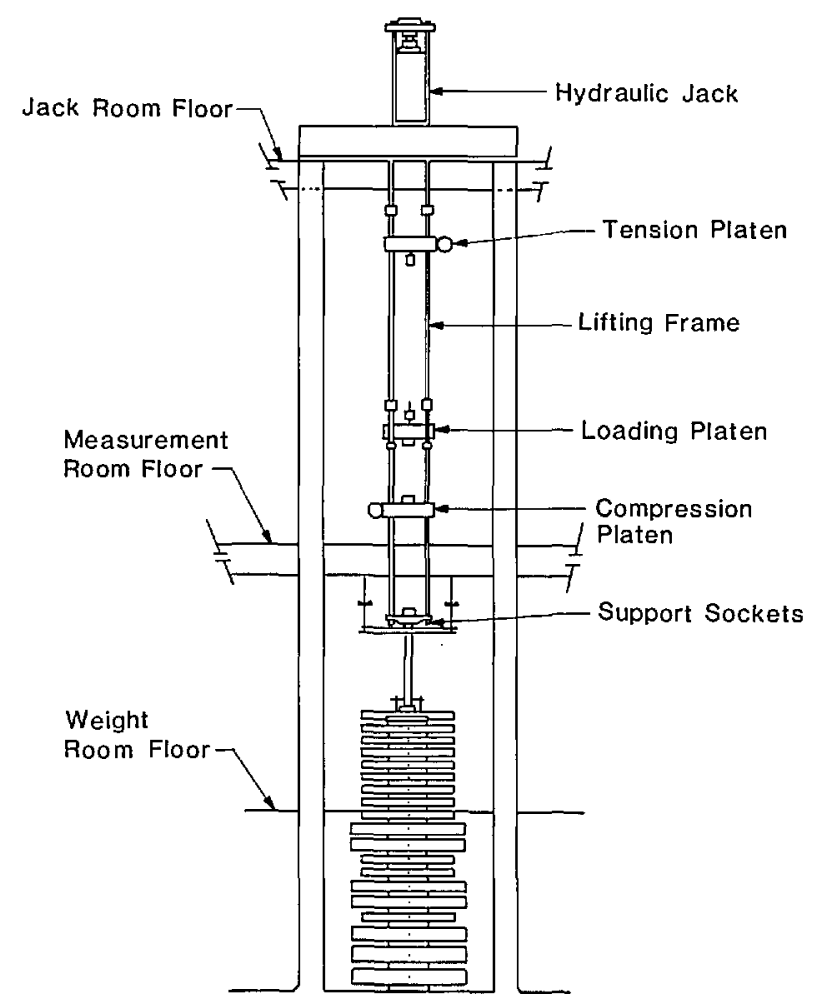

Figure 2. The NIST $300 \mathrm{klbf}$ deadweight machine. 


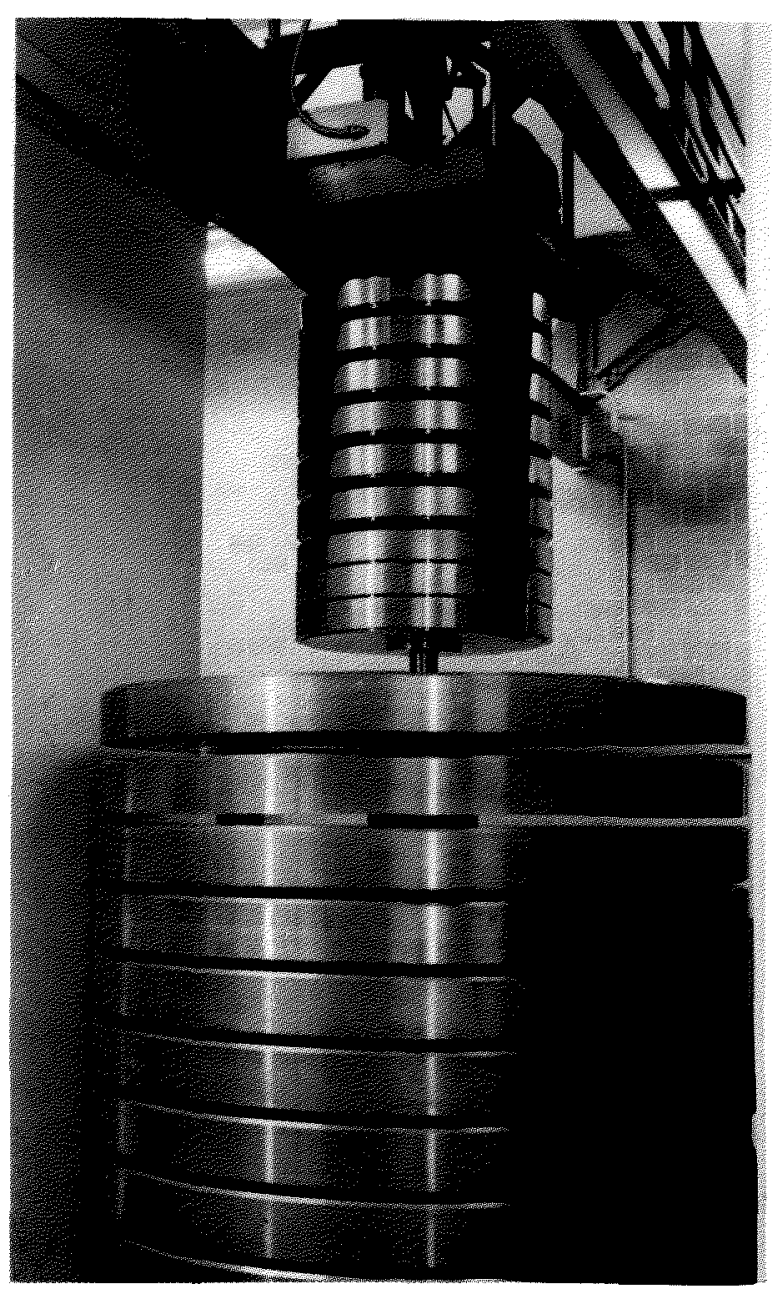

Figure 3. The NIST 112 klbf deadweight machine.

by the screw jacks, in sequence, beginning with the bottom weight of the stack. The time required to apply the capacity load in each machine is given in Table 1. The vertical positions of the compression and tension platens of the lifting frame are adjusted as required to fit each calibration setup. The maximum setup space in each machine is given in Table 1 . The safety nuts are adjusted so that they will support the deadweight load if the calibration setup becomes unstable. The vertical members of the loading frames are not clearly visible in Figs. 1 and 2 because the widths of the loading frames are approximately equal to the widths of the respective lifting frames.

\subsection{The PTB Force Standard Machines}

To cover the force range included in the intercomparison, two PTB force standard machines were utilized. In the first machine, the $1 \mathrm{MN}$ ma-

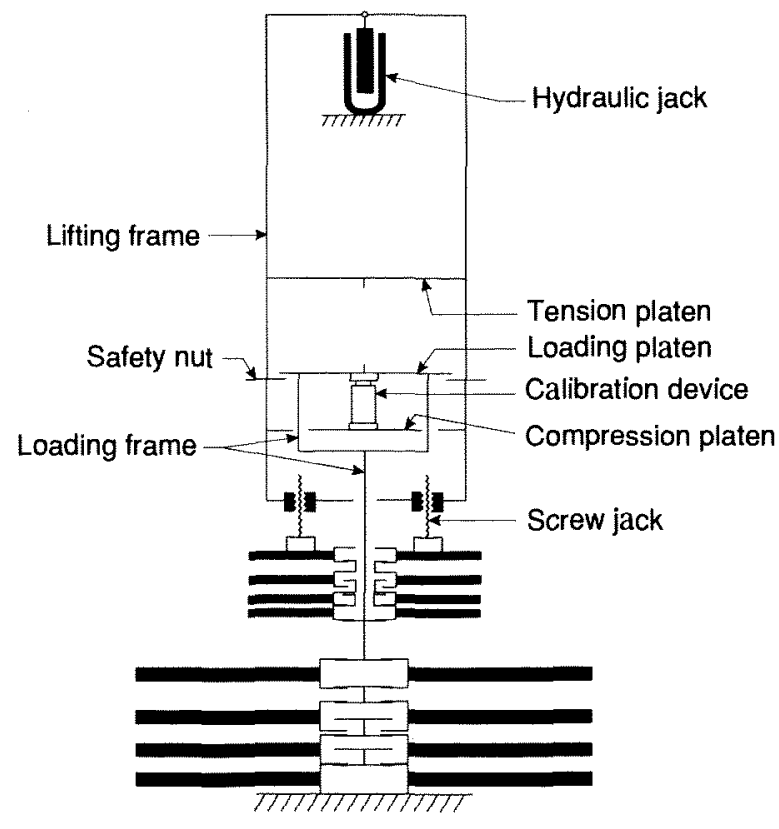

Figure 4. Schematic drawing of the three largest NIST deadweight machines.

chine, forces are generated by deadweights. In the second machine, the $15 \mathrm{MN}$ machine, forces are generated by means of a hydraulic force multiplication system. These machines have been described in detail in Refs. $[1,3,4]$.

A schematic diagram of the $1 \mathrm{MN}$ deadweight machine is shown in Fig. 5. A schematic view of the $15 \mathrm{MN}$ hydraulic force standard machine is shown in Fig. 6.

The overall uncertainty of the force realized in the hydraulic standard force machine has been estimated to be about $100 \mathrm{ppm}$ [5]. The uncertainty of the $1 \mathrm{MN}$ machine is comparable to that of the NIST deadweight machines.

\section{Force Transfer Standards}

A total of six force transducers were used in the intercomparison. Among these, five force transducers, having capacities of $100 \mathrm{kN}, 200 \mathrm{kN}, 500 \mathrm{kN}, 1$ $\mathrm{MN}$, and $5 \mathrm{MN}$, have been in use at PTB over a substantial period of time. Accordingly, the behavior of these five force transducers is well known as is their long-term stability [1]. The history of the sixth transducer used, the $4.7 \mathrm{MN}$ transducer, is not well documented. A complete description of each transducer can be found in Ref. [1].

To minimize the uncertainty associated with the indicating instrument a high-resolution indicator having a good stability was chosen. The resolution of the selected indicator is $1 \mathrm{ppm}$. 


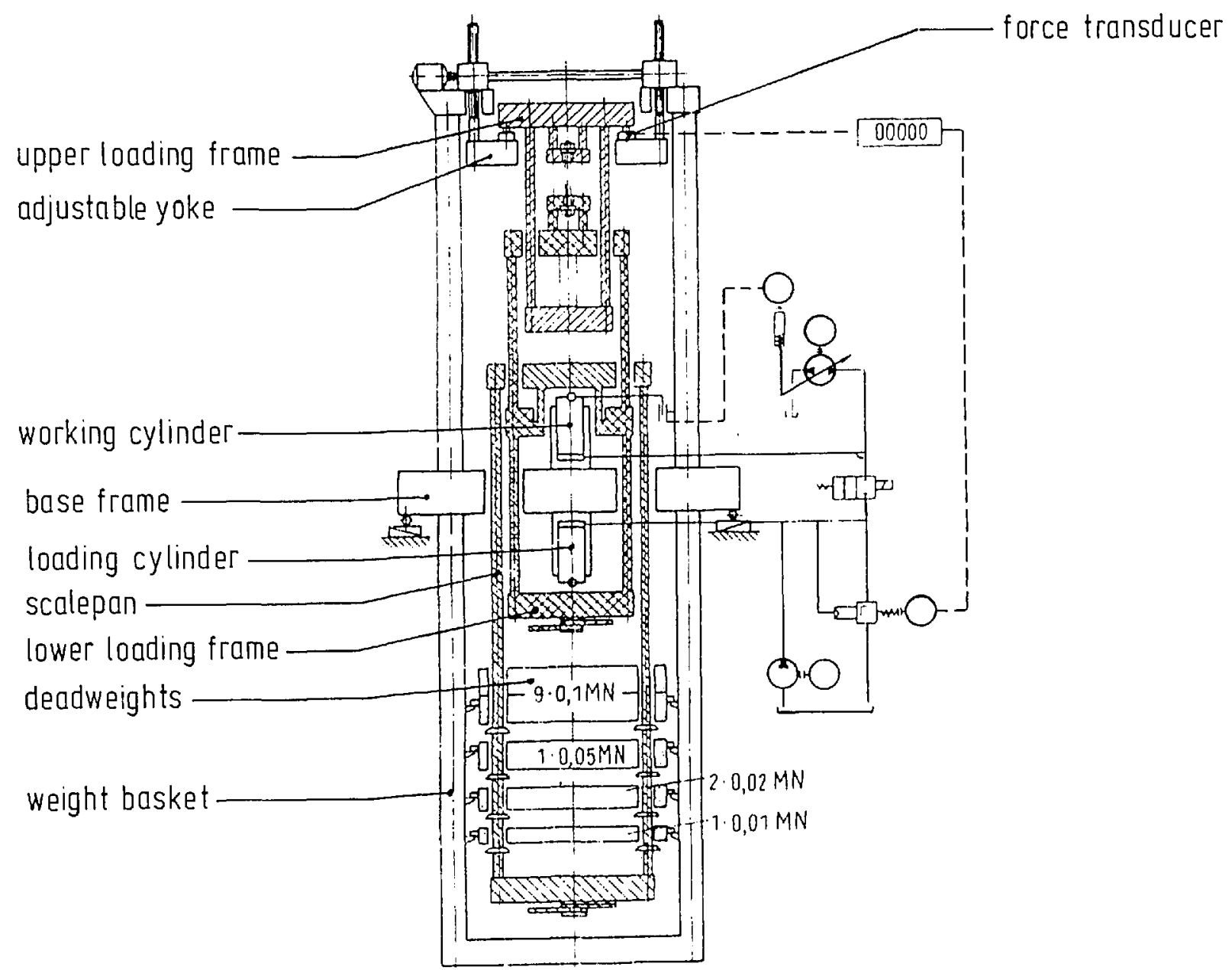

Figure 5. Schematic diagram of the PTB $1 \mathrm{MN}$ deadweight machine.

Prior to the start of the intercomparison, measurements were conducted at PTB, using a calibrating standard bridge to ascertain the reliability of the indicator when different main frequencies (50 and $60 \mathrm{~Hz}$ in Germany and USA, respectively) and different voltages (220 and $115 \mathrm{~V}$ in Germany and USA, respectively) are used. No significant differences were found.

\section{Measurement Procedure}

In developing the procedure utilized to perform the intercomparison, great care was given to minimize the effects of those parameters that are known to contribute to the measurement uncertainty. The following subsections describes these parameters and the ways in which their effects were minimized.

\subsection{Time Interval}

The difference between the output of a transducer at a load and its output when no load is applied represents the response of the transducer to that load. When a load is applied to a force transducer or when the force transducer is unloaded, there are initial mechanical, thermal and electrical responses in the various interconnected elements, followed by a delayed creep response or drift in the output of the transducer as the elements approach a new equilibrium condition. The process may be further complicated by local heating due to electrical-power dissipation by the strain-measuring bridge.

Although different force transducers exhibit different creep patterns [6], in general, the creep rate decreases greatly during the first few minutes following loading or unloading. To minimize the effect of creep, for each force transducer included in 


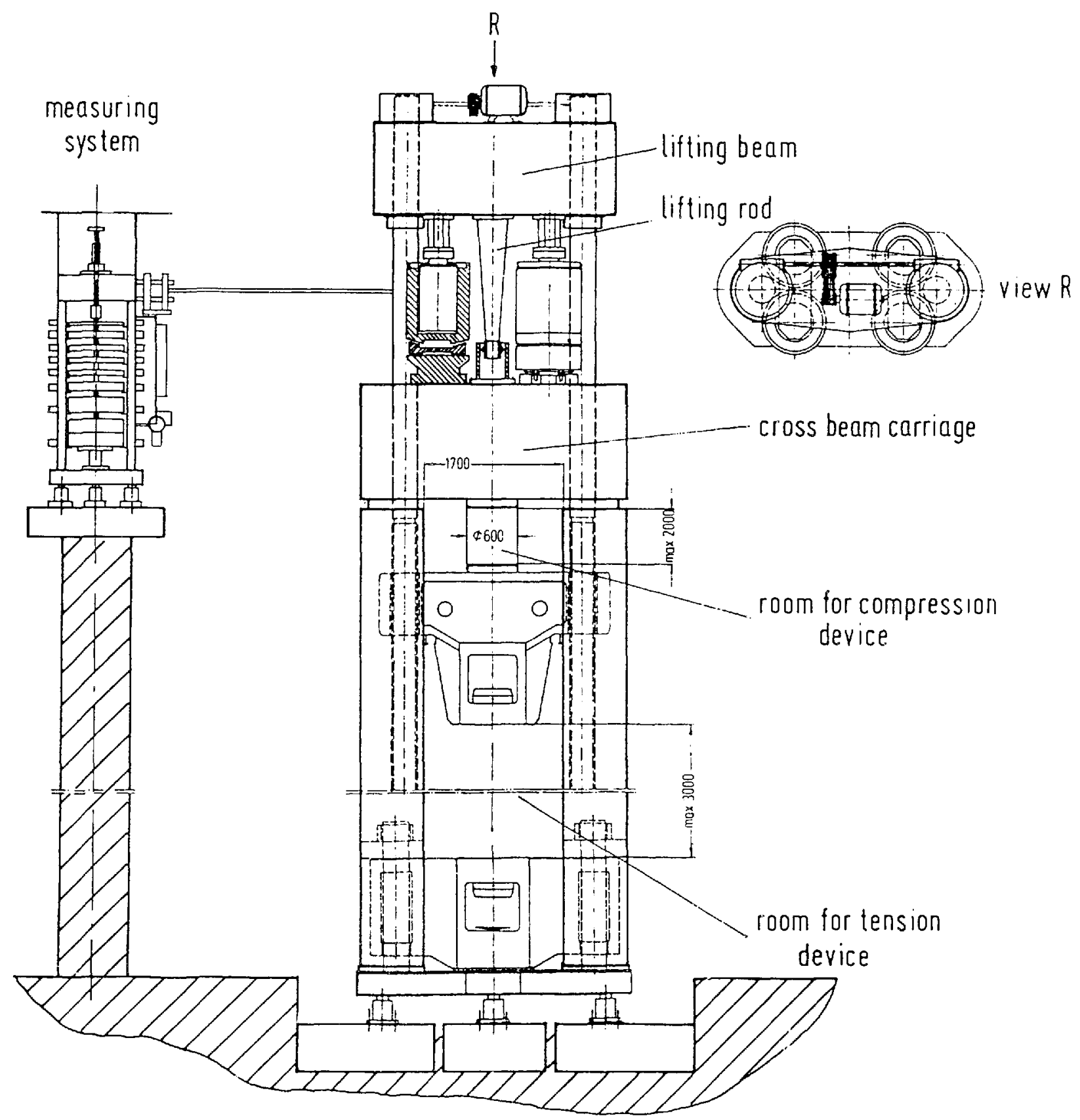

Figure 6. Schematic diagram of the PTB 15 MN hydraulie foree standard maehine.

the intercomparison, the time required to achieve a stable response following loading and unloading was determined prior to the start of the intercomparison. In most instances it was found that a $3 \mathrm{~min}$ time delay between the initiation of the loading (or unloading) and the actual reading was adequate. When tests were conducted in the NIST $300 \mathrm{klbf}$ and 1 Mlbf standard machines an additional 1.5 min was allowed to account for the longer loading and unloading times of these very-large deadweight machines.

In each instance, each set of measurements was duplicated once. In all cases a 3 min delay time was introduced between the completion of the initial set of measurements and the initiation of the duplicate set of measurements. 


\subsection{Machine-Transducer Interaction}

Machine-transducer interactions can significantly influence measurement accuracy. Normal imperfections in the alignment of loading machines and force transducers can result in significant bending, shear, and twist components of deformation in the force transducer. To minimize the errors due to these nonaxial components of deformation, it is desirable to sample the response of the force transducer at several symmetrically distributed positions [7,8]. For this reason, the response of each force transducer was obtained at five positions relative to the axis of the machine $\left(0^{\circ}, 90^{\circ}, 180^{\circ}, 270^{\circ}, 360^{\circ}\right)$.

While at the $0^{\circ}$ position and prior to the start of a measurement cycle, the force transducer was exercised by applying the maximum test load three times, returning to zero after each maximum load application. After a $3 \mathrm{~min}$ delay, with the force transducer still in the same position, two sets of measurements were obtained, each separated by a 3 min interval. Then, the force transducer was rotated by $90^{\circ}$ and two new sets of measurements, each separated by a $3 \mathrm{~min}$ interval, were obtained, and so on. A special rotating mechanism, installed underneath the force transducer, allowed the transducer to be rotated rapidly through all the positions. During a measurement cycle (two sets of measurements at five positions) the force transducer was exercised only once at the beginning of the cycle at the $0^{\circ}$ position.

\subsection{Ambient Conditions}

The measurements were carried out at $(23 \pm 0.5){ }^{\circ} \mathrm{C}$, the usual laboratory conditions at NIST. Normally at PTB the laboratories are maintained at $(20 \pm 1)^{\circ} \mathrm{C}$. However, a week prior to the initiation of the measurements, the temperature of the PTB laboratories was increased to $(23 \pm 1)^{\circ} \mathrm{C}$. Both the force transducers and the indicator were kept at this temperature for a week prior to the initiation of measurements.

\subsection{Force Steps}

The forces realized in the PTB $15 \mathrm{MN}$ standard machine were compared to the forces realized in the NIST 1 Mlbf deadweight machine. The forces realized in the PTB $1 \mathrm{MN}$ deadweight machine were compared to those realized in the NIST 112 klbf, $300 \mathrm{klbf}$, and $1 \mathrm{Mlbf}$ deadweight machines. The loads selected for machine intercomparison are listed in Tables 2, 3, and 4. Load selection was dictated by the constraints of the force standard machines intercompared, and the following criteria:

1. Limit the measurement range so that no measurements are made below $40 \%$ of the force transducer capacity. However, because of the limitation of the machines in some instances data were taken with loads as low as $20 \%$.

2. Use only load sequences that can be applied monotonically;

3. For each force standard machine intercompared, select the same loads.

The following relationship was used to convert pound force to newtons:

$$
1 \mathrm{lbf}=4.448222 \mathrm{~N} \text {. }
$$

Table 2. Load chosen to intercompare the PTB $1 \mathrm{MN}$ and the NIST 112 klbf standard machines

\begin{tabular}{cccr}
\hline \hline $\begin{array}{l}\text { Force transducer } \\
\text { capacity, kN }\end{array}$ & $\begin{array}{c}\text { Seleeted loads in } \\
\text { PTB machine, } \mathrm{kN}\end{array}$ & \multicolumn{2}{c}{$\begin{array}{c}\text { Selected loads in } \\
\text { NIST machine }\end{array}$} \\
\hline \multirow{2}{*}{100} & 50 & $\mathrm{kN}$ & $\begin{array}{r}\text { (klbf) } \\
(11)\end{array}$ \\
& 100 & 48.9304 & $(22)$ \\
200 & 100 & 102.3091 & $(23)$ \\
& 150 & 151.2395 & $(34)$ \\
& 200 & 200.1700 & $(45)$ \\
500 & 200 & & \\
& 300 & 200.1700 & $(45)$ \\
& 400 & 298.0309 & $(67)$ \\
& 500 & 400.3400 & $(90)$ \\
& & 498.2009 & $(112)$ \\
\hline
\end{tabular}

Table 3. Loads chosen to intercompare the PTB $1 \mathrm{MN}$ and the NIST 300 klbf standard machines

\begin{tabular}{cccr}
\hline \hline $\begin{array}{c}\text { Force transducer } \\
\text { capacity, kN }\end{array}$ & $\begin{array}{c}\text { Selected loads in } \\
\text { PTB machine, kN }\end{array}$ & \multicolumn{2}{c}{$\begin{array}{c}\text { Selected loads in } \\
\text { NIST machine }\end{array}$} \\
\hline \multirow{2}{*}{200} & & $\mathrm{kN}$ & $(\mathrm{klbf})$ \\
& 90 & 88.9644 & $(20)$ \\
& 130 & 133.4467 & $(30)$ \\
& 180 & 177.9289 & $(40)$ \\
500 & 220 & 222.4111 & $(50)$ \\
& 310 & 311.3755 & $(70)$ \\
& 400 & 400.3400 & $(90)$ \\
1000 & 410 & & \\
& 540 & 400.3400 & $(90)$ \\
& 670 & 663.7866 & $(120)$ \\
& 800 & 800.6800 & $(180)$ \\
& 930 & 934.1266 & $(210)$ \\
\hline
\end{tabular}


Table 4. Load chosen to intercompare the PTB $1 \mathrm{MN}, 15 \mathrm{MN}$ and the NIST 1 Mlbf standard machines

\begin{tabular}{|c|c|c|c|}
\hline \multirow{4}{*}{$\begin{array}{c}\text { Force transducer } \\
\text { capacity, kN } \\
1000\end{array}$} & \multirow{3}{*}{$\begin{array}{c}\text { Selected loads in } \\
\text { PTB machine, kN } \\
220\end{array}$} & \multicolumn{2}{|c|}{$\begin{array}{l}\text { Selected loads in } \\
\text { NIST machine }\end{array}$} \\
\hline & & $\mathrm{kN}$ & (klbf) \\
\hline & & 222.4111 & $(50)$ \\
\hline & 440 & 444.8222 & $(100)$ \\
\hline & 660 & 667.2333 & (150) \\
\hline & 880 & 889.6444 & (200) \\
\hline \multirow[t]{2}{*}{4700} & 900 & 889.6444 & (200) \\
\hline & 1800 & 1779.2888 & (400) \\
\hline \multirow[t]{2}{*}{ and } & 2700 & 2668.9332 & (600) \\
\hline & 3600 & 3558.5776 & $(800)$ \\
\hline 5000 & 4500 & 4448.2220 & (1000) \\
\hline
\end{tabular}

\section{Measurements Results}

An effort was made to select for inclusion in the intercomparison similar loads at both PTB and NIST. However, because of machine limitations, the loads actually used, while similar, were significantly different as can be seen in Tables 2 through 4. For this reason, the NIST readings were normalized to correspond to the PTB applied force steps in accordance with the following equation:

$$
\begin{aligned}
& \text { NIST normalized indicator reading } \\
& =\frac{\text { PTB applied force } \mathrm{kN}}{\text { NIST applied force } \mathrm{kN}} \\
& \times \text { NIST indicator reading, }
\end{aligned}
$$

where the NIST indicator reading is the net indicator reading obtained by subtracting the zero indicator reading from the reading at load.

\subsection{Comparison of Forces in the Range of $\mathbf{5 0}$ to $500 \mathrm{kN}$}

Three force transducers having nominal capacities of 100,200 , and $500 \mathrm{kN}$ were used to intercompare, over a range of 50 to $500 \mathrm{kN}$, the forces realized in the NIST $112 \mathrm{klbf}$ deadweight machine and the forces realized at PTB. The force steps selected for this intercomparison were $50,100,150$, $200,300,400$, and $500 \mathrm{kN}$.

The measurement variability in each series of measurements, at each force step and at each force transducer position, expressed as the relative data spread between runs, is given in Tables 5, 6, and 7 for the 100,200 , and $500 \mathrm{kN}$ force transducers,
Table 5. Relative data spread between runs for the $100 \mathrm{kN}$ force transducer as a function of rotational position: 50 to 500 $\mathrm{kN}$ range

\begin{tabular}{lrrrrr}
\hline \hline \multirow{3}{*}{ Institute } & $\begin{array}{c}\text { Applicd } \\
\text { force }\end{array}$ & $\begin{array}{c}0^{\circ} \\
\mathrm{ppm}\end{array}$ & $\begin{array}{c}\text { Rotational position } \\
\text { ppm }\end{array}$ & $\begin{array}{c}180^{\circ} \\
\mathrm{ppm}\end{array}$ & $\begin{array}{c}270^{\circ} \\
\mathrm{ppm}\end{array}$ \\
\hline PTB initial & $50 \mathrm{kN}$ & 0 & 6 & 24 & 6 \\
& $100 \mathrm{kN}$ & 2 & 0 & 1 & 4 \\
NIST & $11 \mathrm{klbf}$ & 4 & 9 & 9 & 8 \\
& $22 \mathrm{klbf}$ & 4 & 17 & 11 & 6 \\
PTB final & $50 \mathrm{kN}$ & 14 & 29 & 31 & 5 \\
& $100 \mathrm{kN}$ & 4 & 6 & 2 & 9 \\
\hline
\end{tabular}

Table 6. Relative data spread between runs for the $200 \mathrm{kN}$ force transducer as a function of rotational position: 50 to 500 $\mathrm{kN}$ range

\begin{tabular}{lcrrrr}
\hline \hline Institute & $\begin{array}{c}\text { Applied } \\
\text { force }\end{array}$ & $\begin{array}{c}0^{\circ} \\
\mathrm{ppm}\end{array}$ & $\begin{array}{c}\text { Rotational position } \\
\text { ppm }\end{array}$ & $\begin{array}{c}180^{\circ} \\
\mathrm{ppm}\end{array}$ & $\begin{array}{r}270^{\circ} \\
\mathrm{ppm}\end{array}$ \\
\hline PTB initial & $100 \mathrm{kN}$ & 9 & 3 & 7 & 6 \\
& $150 \mathrm{kN}$ & 9 & 3 & 2 & 6 \\
& $200 \mathrm{kN}$ & 15 & 3 & 23 & 5 \\
NIST & $23 \mathrm{klbf}$ & 21 & 14 & 4 & 47 \\
& $34 \mathrm{klbf}$ & 8 & 4 & 1 & 5 \\
& $45 \mathrm{klbf}$ & 9 & 2 & 2 & 14 \\
PTB final & $100 \mathrm{kN}$ & 12 & 2 & 5 & 5 \\
& $150 \mathrm{kN}$ & 12 & 2 & 18 & 3 \\
& $200 \mathrm{kN}$ & 44 & 11 & 1 & 6 \\
\hline
\end{tabular}

Table 7. Relative data spread between runs for the $500 \mathrm{kN}$

\begin{tabular}{|c|c|c|c|c|c|}
\hline \multirow[b]{2}{*}{ Institute } & \multirow[b]{2}{*}{$\begin{array}{l}\text { Applicd } \\
\text { force }\end{array}$} & \multicolumn{4}{|c|}{ Rotational position } \\
\hline & & $\begin{array}{c}0^{\circ} \\
\mathrm{ppm}\end{array}$ & $\begin{array}{c}90^{\circ} \\
\mathrm{ppm}\end{array}$ & $\begin{array}{l}180^{\circ} \\
\mathrm{ppm}\end{array}$ & $\begin{array}{l}270^{\circ} \\
\mathrm{ppm}\end{array}$ \\
\hline \multirow[t]{4}{*}{ PTB initial } & $200 \mathrm{kN}$ & 1 & 4 & 1 & 10 \\
\hline & $300 \mathrm{kN}$ & 8 & 2 & 3 & 7 \\
\hline & $400 \mathrm{kN}$ & 10 & 2 & 1 & 3 \\
\hline & $500 \mathrm{kN}$ & 9 & 1 & 0 & 1 \\
\hline \multirow[t]{4}{*}{ NIST } & $45 \mathrm{klbf}$ & 13 & 1 & 9 & 21 \\
\hline & $67 \mathrm{klbf}$ & 8 & 18 & 2 & 0 \\
\hline & $90 \mathrm{klbf}$ & 5 & 7 & 4 & 4 \\
\hline & $112 \mathrm{klbf}$ & 7 & 3 & 1 & 3 \\
\hline \multirow[t]{4}{*}{ PTB final } & $200 \mathrm{kN}$ & 9 & 6 & 6 & 1 \\
\hline & $300 \mathrm{kN}$ & 5 & 3 & 0 & 4 \\
\hline & $400 \mathrm{kN}$ & 9 & 0 & 1 & 1 \\
\hline & $500 \mathrm{kN}$ & 2 & 2 & 0 & 1 \\
\hline
\end{tabular}
force transducer as a function of rotational position: 50 to 500 $\mathrm{kN}$ range 
respectively. The relative spread between runs was calculated by taking the difference between the first and second readings and dividing the result by the initial reading. Tables 5 through 7 show that, for each force step, the spread in the data, for all measurements performed at both NIST and PTB, is below $50 \mathrm{ppm}$.

The net mean force transducer outputs measured during the NIST measurements, the initial and final PTB measurements, and those obtained by averaging the initial and final PTB measurements are presented in Table 8 . The values in Table 8 are in indicator units.

The relative differences between the average indicator readings at NIST and the corresponding average indicator readings at PTB are listed in Table 9 as a function of force transducer and force step. The values shown in Table 9 were obtained by taking the mean reading at NIST, subtracting from it

Table 8. Force transducer outputs measured at NIST and PTB: 50 to $500 \mathrm{kN}$ range

\begin{tabular}{lccccc}
\hline $\begin{array}{l}\text { Trans- } \\
\text { ducer } \\
\mathrm{kN}\end{array}$ & $\begin{array}{c}\text { Force } \\
\text { stcp } \\
\mathrm{kN}\end{array}$ & $\begin{array}{c}\text { PTB } \\
\text { initial }\end{array}$ & $\begin{array}{l}\text { PTB } \\
\text { final }\end{array}$ & $\begin{array}{c}\text { PTB } \\
\text { mean }\end{array}$ & NIST \\
\hline 100 & 50 & 1.069592 & 1.069593 & 1.069593 & 1.069559 \\
& 100 & 2.137819 & 2.137841 & 2.137830 & 2.137778 \\
& & & & & \\
200 & 100 & 0.999438 & 0.999449 & 0.999444 & 0.999440 \\
& 150 & 1.499222 & 1.499257 & 1.499240 & 1.499246 \\
& 200 & 1.999049 & 1.999081 & 1.999065 & 1.999087 \\
500 & 200 & 0.799180 & 0.799230 & 0.799205 & 0.799214 \\
& 300 & 1.198875 & 1.198944 & 1.198909 & 1.198908 \\
& 400 & 1.598594 & 1.598667 & 1.598630 & 1.598628 \\
& 500 & 1.998344 & 1.998420 & 1.998382 & 1.998382 \\
& & & & & \\
\hline
\end{tabular}

Table 9. Relative differences between the NIST and PTB mean readings for the force transducer tested in the $112 \mathrm{klbf}$ deadweight machine

\begin{tabular}{ccccc}
\hline \hline $\begin{array}{c}\text { Transducer } \\
k N\end{array}$ & $\begin{array}{c}\text { Force step } \\
\mathrm{kN}\end{array}$ & $\begin{array}{c}\text { PTB initial } \\
\mathrm{ppm}\end{array}$ & $\begin{array}{c}\text { PTB final } \\
\mathrm{ppm}\end{array}$ & $\begin{array}{c}\text { PTB mean } \\
\mathrm{ppm}\end{array}$ \\
\hline 100 & 50 & -31 & -32 & -31 \\
& 100 & -19 & -29 & -24 \\
& & & & \\
200 & 100 & 2 & -10 & -4 \\
& 150 & 16 & -8 & 4 \\
& 200 & 19 & 3 & 11 \\
500 & & & & \\
& 200 & 43 & -19 & 12 \\
& 300 & 28 & -30 & -1 \\
& 400 & 21 & -24 & -1 \\
& 500 & 19 & -19 & 0 \\
\hline
\end{tabular}

the corresponding mean reading at $\mathrm{PTB}$, and then dividing the result by the corresponding mean value of initial and final PTB readings. The values shown are rounded to the nearest ppm.

The average deviations in the mean PTB data relative to the mean NIST data for all force transducers and force steps examined (i.e., last column in Table 9) are given in Fig. 7. Figure 7 shows that the agreement between the data obtained at NIST and PTB is excellent. The deviations fall within a band ranging from -31 to $12 \mathrm{ppm}$.

\subsection{Comparison of Forces in the Range of $90 \mathrm{kN}$ to $1 \mathrm{MN}$}

Three force transducers having nominal capacities of $200 \mathrm{kN}, 500 \mathrm{kN}$, and $1 \mathrm{MN}$ were used to intercompare, over a range of $90 \mathrm{kN}$ to $1 \mathrm{MN}$, the forces realized in the NIST $300 \mathrm{klbf}$ deadweight machine and the forces realized at PTB. The force steps selected for this intercomparison were 90 , $130,180,220,310,400,410,540,670,800$, and 930 $\mathrm{kN}$. When the program was planned originally, it was not anticipated that the 90,130 , and $180 \mathrm{kN}$ force steps would be included in this subset of intercomparison. Accordingly, the first series of measurements performed at PTB did not include measurements for these force steps.

The measurement variability in each series of measurements, at each force step and each force transducer position, expressed as the relative data spread between runs, is given in Tables 10,11 , and 12 for the $200 \mathrm{kN}, 500 \mathrm{kN}$, and $1 \mathrm{MN}$ force transducers, respectively. The relative spread between

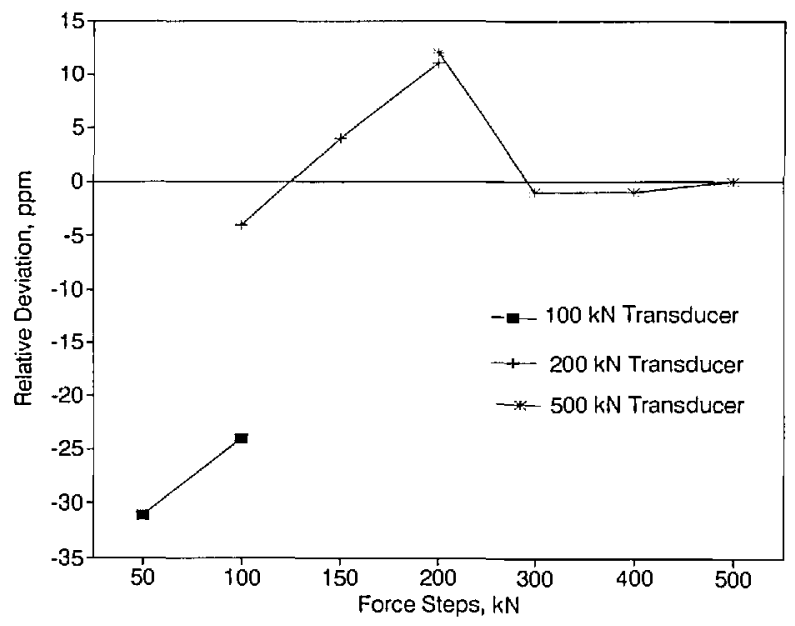

Figure 7. Deviations in the mean PTB data relative to the mean NIST data for the 50 to $500 \mathrm{kN}$ range. 
Table 10. Relative data spread between runs for the $200 \mathrm{kN}$ force transducer as a function of rotational position: $90 \mathrm{kN}$ to 1 MN range

\begin{tabular}{lcrrrr}
\hline \hline Institute & $\begin{array}{c}\text { Applied } \\
\text { force }\end{array}$ & $\begin{array}{c}0^{\circ} \\
\mathrm{ppm}\end{array}$ & $\begin{array}{c}\text { Rotational position } \\
\mathrm{ppm}\end{array}$ & $\begin{array}{c}180^{\circ} \\
\mathrm{ppm}\end{array}$ & $\begin{array}{r}270^{\circ} \\
\mathrm{ppm}\end{array}$ \\
\hline PTB final & $90 \mathrm{kN}$ & 3 & 11 & 6 & 23 \\
& $130 \mathrm{kN}$ & 21 & 8 & 3 & 8 \\
& $180 \mathrm{kN}$ & 1 & 13 & 3 & 2 \\
NIST & $20 \mathrm{klbf}$ & 0 & 1 & 3 & 3 \\
& $30 \mathrm{klbf}$ & 6 & 4 & 1 & 4 \\
& $40 \mathrm{klbf}$ & 11 & 4 & 2 & 1 \\
\hline
\end{tabular}

Table 11. Relative data spread between runs for the $500 \mathrm{kN}$ force transducer as a function of rotational position: $90 \mathrm{kN}$ to 1 MN range

\begin{tabular}{lccccc}
\hline \hline Institute & Applied & \multicolumn{4}{c}{ Rotational position } \\
& force & $\begin{array}{c}0^{\circ} \\
\mathrm{ppm}\end{array}$ & $\begin{array}{c}90^{\circ} \\
\mathrm{ppm}\end{array}$ & $\begin{array}{c}180^{\circ} \\
\mathrm{ppm}\end{array}$ & $\begin{array}{c}270^{\circ} \\
\mathrm{ppm}\end{array}$ \\
\hline PTB initial & $220 \mathrm{kN}$ & 5 & 5 & 1 & 16 \\
& $310 \mathrm{kN}$ & 9 & 2 & 10 & 13 \\
& $400 \mathrm{kN}$ & 1 & 1 & 13 & 9 \\
NIST & & & & & \\
& $50 \mathrm{klbf}$ & 0 & 4 & 4 & 4 \\
& $70 \mathrm{klbf}$ & 2 & 3 & 5 & 5 \\
& $90 \mathrm{klbf}$ & 5 & 10 & 2 & 4 \\
PTB final & $220 \mathrm{kN}$ & 2 & 1 & 3 & 6 \\
& $310 \mathrm{kN}$ & 2 & 6 & 2 & 2 \\
& $400 \mathrm{kN}$ & 6 & 1 & 3 & 1 \\
\hline
\end{tabular}

Table 12. Relative data spread between runs for the $1 \mathrm{MN}$ force transducer as a function of rotational position: $90 \mathrm{kN}$ to $1 \mathrm{MN}$ range

\begin{tabular}{lcrrrr}
\hline \hline \multirow{3}{*}{ Institute } & Applied & \multicolumn{4}{c}{ Rotational position } \\
& force & $\begin{array}{r}0^{\circ} \\
\text { ppm }\end{array}$ & $\begin{array}{c}90^{\circ} \\
\text { ppm }\end{array}$ & $\begin{array}{c}180^{\circ} \\
\text { ppm }\end{array}$ & $\begin{array}{r}270^{\circ} \\
\text { ppm }\end{array}$ \\
\hline PTB initial & $410 \mathrm{kN}$ & 2 & 17 & 0 & 0 \\
& $540 \mathrm{kN}$ & 3 & 25 & 25 & 31 \\
& $670 \mathrm{kN}$ & 3 & 9 & 2 & 10 \\
& $800 \mathrm{kN}$ & 1 & 10 & 2 & 4 \\
& $930 \mathrm{kN}$ & 3 & 2 & 2 & 6 \\
NIST & & & & & \\
& $90 \mathrm{klbf}$ & 5 & 27 & 5 & 20 \\
& $120 \mathrm{klbf}$ & 0 & 7 & 2 & 2 \\
& $150 \mathrm{klbf}$ & 4 & 0 & 3 & 2 \\
& $180 \mathrm{klbf}$ & 5 & 1 & 1 & 4 \\
& $210 \mathrm{klbf}$ & 2 & 4 & 4 & 5 \\
& & & & & \\
PTB final & $410 \mathrm{kN}$ & 2 & 0 & 1 & 6 \\
& $540 \mathrm{kN}$ & 12 & 8 & 1 & 4 \\
& $670 \mathrm{kN}$ & 2 & 8 & 7 & 4 \\
& $800 \mathrm{kN}$ & 10 & 4 & 2 & 1 \\
& $930 \mathrm{kN}$ & 13 & 8 & 4 & 2 \\
\hline
\end{tabular}

runs was calculated by taking the difference between the first and second readings and dividing the result by the initial reading. Tables 10 through 12 show that, for each force step, the spread of the data is below $35 \mathrm{ppm}$ for all measurements performed at both PTB and NIST.

The net mean force transducer outputs measured during the NIST measurements, the initial and final PTB measurements, and those obtained by averaging the initial and final PTB measurements are presented in Table 13 . The values shown are in indicator units.

The relative differences between the average indicator readings at NIST and the corresponding readings at $\mathrm{PTB}$ are listed in Table 14 as a function of force transducer and force step. The values shown in Table 14 were obtained as described in Sec. 5.1 except that, for the $200 \mathrm{kN}$ force transducer, the values shown were obtained by taking the mean reading at NIST, subtracting from it the corresponding mean final $\mathrm{PTB}$ reading, and dividing the result by the mean final PTB reading. All the values in Table 14 were rounded to the nearest ppm.

When evaluating the differences in the forces realized at PTB and NIST in the range between 220 and $400 \mathrm{kN}$, that is the forces determined using the $500 \mathrm{kN}$ force transducer, only the relative differences between NIST and the final PTB data are meaningful because the initial set of measurements obtained at PTB were found to contain systematic errors. This is the reason why the decision was

Table 13. Force transducer outputs mcasured at NIST and PTB: $90 \mathrm{kN}$ to $1 \mathrm{MN}$ range

\begin{tabular}{cccccc}
\hline \hline $\begin{array}{c}\text { Trans- } \\
\text { ducc } \\
\mathrm{kN}\end{array}$ & $\begin{array}{c}\text { Force } \\
\text { stcp } \\
\mathrm{kN}\end{array}$ & $\begin{array}{c}\text { PTB } \\
\text { initial }\end{array}$ & $\begin{array}{c}\text { PTB } \\
\text { final }\end{array}$ & $\begin{array}{c}\text { PTB } \\
\text { mean }\end{array}$ & NIST \\
\hline $200^{\mathrm{a}}$ & 90 & & 0.899500 & & 0.899500 \\
& 130 & & 1.299331 & & 1.299366 \\
& 180 & & 1.799171 & & 1.799204 \\
$500^{\mathrm{b}}$ & 220 & 0.879081 & 0.879165 & 0.879123 & 0.879184 \\
& 310 & 1.238808 & 1.238898 & 1.238853 & 1.238927 \\
& 400 & 1.598538 & 1.598644 & 1.598591 & 1.598666 \\
1000 & 410 & 0.835596 & 0.835609 & 0.835602 & 0.835623 \\
& 540 & 1.100592 & 1.100621 & 1.100607 & 1.100618 \\
& 670 & 1.365630 & 1.365669 & 1.365649 & 1.365654 \\
& 800 & 1.630647 & 1.630694 & 1.630670 & 1.630684 \\
& 930 & 1.895624 & 1.895674 & 1.895649 & 1.895656
\end{tabular}

\footnotetext{
a No initial PTB mcasurements werc taken with this transducer. b Initial PTB measurements contained systematic errors and should not be used to intercompare the forces achieved in the NIST 300 klbf deadweight machine with those achieved at PTB.
} 
Table 14. Relative differences between NIST and PTB readings for the force transducers tested in the $300 \mathrm{klbf}$ deadweight machine

\begin{tabular}{ccccc}
\hline \hline $\begin{array}{c}\text { Transduccr } \\
\text { kN }\end{array}$ & $\begin{array}{c}\text { Foree step } \\
\text { kN }\end{array}$ & $\begin{array}{c}\text { PTB initial } \\
\text { ppm }\end{array}$ & $\begin{array}{c}\text { PTB final } \\
\text { ppm }\end{array}$ & $\begin{array}{c}\text { PTB mean } \\
\text { ppm }\end{array}$ \\
\hline $200^{\mathrm{a}}$ & 90 & & 0 & \\
& 130 & & 27 & \\
& 180 & & 18 & \\
$500^{\mathrm{b}}$ & 220 & 117 & 22 & 69 \\
& 310 & 96 & 23 & 60 \\
& 400 & 80 & 14 & 47 \\
1000 & 410 & 32 & 17 & 25 \\
& 540 & 24 & -3 & 10 \\
& 670 & 18 & -11 & 4 \\
& 800 & 23 & -6 & 9 \\
& 930 & 17 & -9 & 4
\end{tabular}

"No initial PTB measurements were taken with this transducer. ${ }^{b}$ Initial PTB measurements contained systematic errors and should not be used to intercompare the forccs achieved in the NIST $300 \mathrm{klbf}$ deadweight machinc with those achieved at PTB.

made to include the $200 \mathrm{kN}$ force transducer in the set of force transducers measured in NIST $300 \mathrm{klbf}$ deadweight machine.

The average deviations in the mean PTB data relative to the mean NIST data for all force steps and all force transducers included in the $90 \mathrm{kN}$ through the $1 \mathrm{MN}$ range are shown in Fig. 8. For both the 200 and $500 \mathrm{kN}$ force transducers, the values shown are based on the final PTB measurements only. The data shown for the $1 \mathrm{MN}$ transducer are based on both the initial and final PTB measurements. Figure 8 shows that the agreement between the data obtained at NIST and PTB is very good. The deviations fall within a band from 0 to $30 \mathrm{ppm}$.

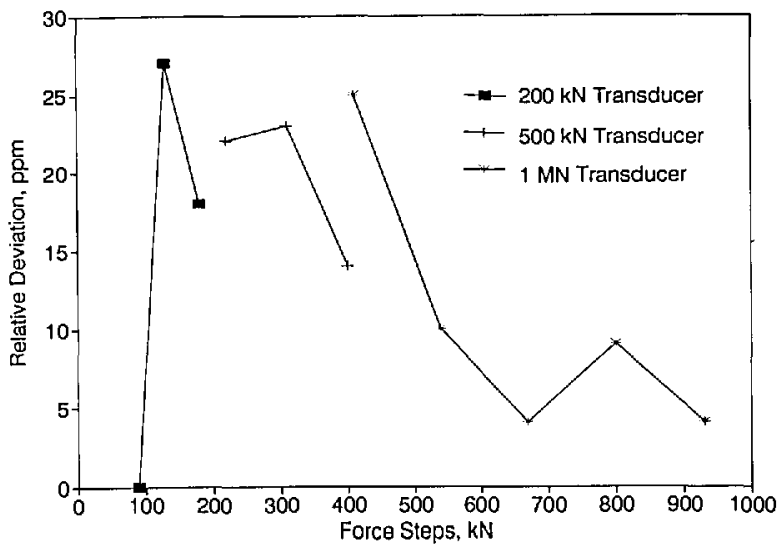

Figure 8. Deviations in the mean PTB data relative to the mean NIST data for the 90 to $1 \mathrm{MN}$ range.

\subsection{Comparison of Forces in the Range of 220 to $4500 \mathrm{kN}$}

Three force transducers having nominal capacities of $1,4.7$, and $5 \mathrm{MN}$ were used to intercompare, over a range of 220 to $4500 \mathrm{kN}$, the forces realized in the NIST $1 \mathrm{Mlbf}$ machine and (a) the forces realized in the $1 \mathrm{MN}$ PTB deadweight machine, and, (b) for forces above $1 \mathrm{MN}$, those achieved in the 15 MN PTB hydraulic multiplication standard machine. The force steps selected for this intercomparison were $220,440,660,880,900,1800,2700$, 3600 , and $4500 \mathrm{kN}$.

The measurement variability in each series of measurements, at each force step and at each force transducer position, expressed as the relative data spread between runs, is given in Tables 15,16 , and 17 for the $1,4.7$, and $5 \mathrm{MN}$ force transducers, respectively. The relative spread between runs was calculated in accordance with the procedure described in Sec. 5.1. Tables 15 through 17 show that for the $1 \mathrm{MN}$ force transducer the largest spread, 57 ppm, was obtained at NIST at the $50 \mathrm{klbf}$ force step. With the other two transducers, the largest spread was obtained at PTB with the maximum, $240 \mathrm{ppm}$, occurring with the $5 \mathrm{MN}$ transducer at the $900 \mathrm{kN}$ force step.

The net mean force transducer outputs measured at NIST and at PTB, and those obtained by averaging the initial and final PTB values are shown in Table 18. The values are in indicator units.

The relative differences between the average indicator readings at NIST and the corresponding average indicator readings at PTB are listed in Table 19 as function of force transducer and force step.

Table 15. Relative data spread between runs for the $1 \mathrm{MN}$ force transducer as a function of rotational position: 220 to $880 \mathrm{kN}$ rangc

\begin{tabular}{lcrrrr}
\hline \hline \multirow{2}{*}{ Institute } & Applicd & \multicolumn{4}{c}{ Rotational position } \\
& force & $\begin{array}{c}0^{\circ} \\
\text { ppm }\end{array}$ & $\begin{array}{c}90^{\circ} \\
\text { ppm }\end{array}$ & $\begin{array}{c}180^{\circ} \\
\text { ppm }\end{array}$ & $\begin{array}{r}270^{\circ} \\
\text { ppm }\end{array}$ \\
\hline PTB initial & $220 \mathrm{kN}$ & 4 & 2 & 13 & 7 \\
& $440 \mathrm{kN}$ & 3 & 11 & 10 & 8 \\
& $660 \mathrm{kN}$ & 16 & 5 & 8 & 5 \\
& $880 \mathrm{kN}$ & 3 & 3 & 2 & 1 \\
& & & & & \\
NIST & $50 \mathrm{klbf}$ & 31 & 51 & 53 & 57 \\
& $100 \mathrm{klbf}$ & 17 & 19 & 19 & 13 \\
& $150 \mathrm{klbf}$ & 4 & 1 & 9 & 25 \\
& $200 \mathrm{klbf}$ & 4 & 0 & 14 & 9 \\
& & & & & \\
PTB final & $220 \mathrm{kN}$ & 0 & 4 & 9 & 27 \\
& $440 \mathrm{kN}$ & 2 & 4 & 4 & 7 \\
& $660 \mathrm{kN}$ & 1 & 11 & 9 & 1 \\
& $880 \mathrm{kN}$ & 5 & 6 & 7 & 0 \\
\hline
\end{tabular}


Table 16. Relative data spread between runs for the $4.7 \mathrm{MN}$ force transducer as a function of rotational position

\begin{tabular}{|c|c|c|c|c|c|}
\hline \multirow[b]{2}{*}{ Institute } & \multirow[b]{2}{*}{$\begin{array}{l}\text { Applied } \\
\text { force }\end{array}$} & \multicolumn{4}{|c|}{ Rotational position } \\
\hline & & $\begin{array}{c}0^{\circ} \\
\mathrm{ppm}\end{array}$ & $\begin{array}{r}90^{\circ} \\
\mathrm{ppm}\end{array}$ & $\begin{array}{l}180^{\circ} \\
\mathrm{ppm}\end{array}$ & $\begin{array}{l}270^{\circ} \\
\text { ppm }\end{array}$ \\
\hline \multirow[t]{5}{*}{ PTB initial } & $900 \mathrm{kN}$ & 95 & 54 & 27 & 27 \\
\hline & $1800 \mathrm{kN}$ & 48 & 34 & 27 & 14 \\
\hline & $2700 \mathrm{kN}$ & 64 & 130 & 140 & 27 \\
\hline & $3600 \mathrm{kN}$ & 37 & 58 & 51 & 20 \\
\hline & $4500 \mathrm{kN}$ & 35 & 38 & 44 & 14 \\
\hline \multirow[t]{5}{*}{ NIST } & 200 klbf & 25 & 33 & 39 & 33 \\
\hline & $400 \mathrm{klbf}$ & 17 & 29 & 25 & 18 \\
\hline & $600 \mathrm{klbf}$ & 34 & 2 & 6 & 6 \\
\hline & $800 \mathrm{klbf}$ & 28 & 6 & 2 & 2 \\
\hline & $1000 \mathrm{klbf}$ & 32 & 8 & 0 & 5 \\
\hline \multirow[t]{5}{*}{ PTB final } & $900 \mathrm{kN}$ & 27 & 110 & 68 & 95 \\
\hline & $1800 \mathrm{kN}$ & 0 & 14 & 48 & $\mathbf{0}$ \\
\hline & $2700 \mathrm{kN}$ & 0 & 59 & 23 & 32 \\
\hline & $3600 \mathrm{kN}$ & 7 & 37 & 10 & 24 \\
\hline & $4500 \mathrm{kN}$ & 3 & 16 & 22 & 38 \\
\hline
\end{tabular}

Table 17. Relative data spread betwcen runs for the $5 \mathrm{MN}$ force transducer as a function of rotational position

\begin{tabular}{|c|c|c|c|c|c|}
\hline \multirow[b]{2}{*}{ Institute } & \multirow[b]{2}{*}{$\begin{array}{l}\text { Applied } \\
\text { force }\end{array}$} & \multicolumn{4}{|c|}{ Rotational position } \\
\hline & & $\begin{array}{c}0^{\circ} \\
\mathrm{ppm}\end{array}$ & $\begin{array}{r}90^{\circ} \\
\mathrm{ppm}\end{array}$ & $\begin{array}{l}180^{\circ} \\
\text { ppm }\end{array}$ & $\begin{array}{l}270^{\circ} \\
\text { ppm }\end{array}$ \\
\hline \multirow[t]{5}{*}{ PTB initial } & $900 \mathrm{kN}$ & 81 & 90 & 18 & 27 \\
\hline & $1800 \mathrm{kN}$ & 4 & 27 & 13 & 27 \\
\hline & $2700 \mathrm{kN}$ & 6 & 42 & 15 & 18 \\
\hline & $3600 \mathrm{kN}$ & 20 & 2 & 20 & 16 \\
\hline & $4500 \mathrm{kN}$ & 14 & 29 & 7 & 13 \\
\hline \multirow[t]{5}{*}{ NIST } & $200 \mathrm{klbf}$ & 11 & 38 & 42 & 82 \\
\hline & $400 \mathrm{klbf}$ & 33 & 25 & 25 & 25 \\
\hline & 600 klbf & 1 & 51 & 1 & 16 \\
\hline & 800 klbf & 0 & 37 & 28 & 1 \\
\hline & $1000 \mathrm{klbf}$ & 12 & 29 & 29 & 14 \\
\hline \multirow[t]{5}{*}{ PTB final } & $900 \mathrm{kN}$ & 110 & 54 & 170 & 240 \\
\hline & $1800 \mathrm{kN}$ & 0 & 130 & 9 & 130 \\
\hline & $2700 \mathrm{kN}$ & 99 & 27 & 110 & 99 \\
\hline & $3600 \mathrm{kN}$ & 36 & 72 & 83 & 130 \\
\hline & $4500 \mathrm{kN}$ & 23 & 23 & 63 & 22 \\
\hline
\end{tabular}

The values shown were obtained in accordance with the procedure given in Sec. 5.1. All values shown in the table were rounded to the nearest ppm. Table 19 shows that overall there was good agreement between the data obtained at PTB and NIST. However, the response of the largest two transducers drifted somewhat during the course of the intercomparison. This drift was most significant with the $5 \mathrm{MN}$ force transducer.
Table 18. Force transducer outputs measured at NIST and PTB: 220 to $4500 \mathrm{kN}$ range

\begin{tabular}{lccccc}
\hline \hline $\begin{array}{l}\text { Trans- } \\
\text { ducer } \\
\mathrm{MN}\end{array}$ & $\begin{array}{c}\text { Force } \\
\text { step } \\
\mathrm{kN}\end{array}$ & $\begin{array}{c}\text { PTB } \\
\text { initial }\end{array}$ & $\begin{array}{c}\text { PTB } \\
\text { final }\end{array}$ & $\begin{array}{c}\text { PTB } \\
\text { mean }\end{array}$ & NIST \\
\hline 1 & 220 & 0.448320 & 0.448304 & 0.448312 & 0.448302 \\
& 440 & 0.896749 & 0.896739 & 0.896744 & 0.896757 \\
& 660 & 1.345272 & 1.345269 & 1.345270 & 1.345285 \\
& 880 & 1.793741 & 1.793745 & 1.793743 & 1.793748 \\
& & & & & \\
4.7 & 900 & 0.557929 & 0.557866 & 0.557898 & 0.557926 \\
& 1800 & 1.115960 & 1.115896 & 1.115928 & 1.115971 \\
& 2700 & 1.673944 & 1.674003 & 1.673974 & 1.673927 \\
& 3600 & 2.231629 & 2.231759 & 2.231694 & 2.231717 \\
& 4500 & 2.789248 & 2.789319 & 2.789284 & 2.789406 \\
5 & & & & & \\
5 & 900 & 0.367344 & 0.367306 & 0.367325 & 0.367351 \\
& 1800 & 0.734166 & 0.734051 & 0.734108 & 0.734212 \\
& 2700 & 1.101155 & 1.100933 & 1.101044 & 1.101248 \\
& 3600 & 1.468967 & 1.468721 & 1.468844 & 1.469005 \\
& 4500 & 1.837706 & 1.837474 & 1.837590 & 1.837671 \\
& & & & & \\
\hline
\end{tabular}

Table 19. Relative differences between the NIST and PTB readings for the force transducers tested in the 1 Mlbf deadweight machine

\begin{tabular}{ccrrr}
\hline \hline $\begin{array}{c}\text { Transducer } \\
\text { MN }\end{array}$ & $\begin{array}{c}\text { Force stcp } \\
\mathrm{kN}\end{array}$ & $\begin{array}{c}\text { PTB initial } \\
\text { ppm }\end{array}$ & $\begin{array}{c}\text { PTB final } \\
\text { ppm }\end{array}$ & $\begin{array}{c}\text { PTB mean } \\
\text { ppm }\end{array}$ \\
\hline 1 & 220 & -40 & -5 & -23 \\
& 440 & 9 & 20 & 14 \\
& 660 & 10 & 12 & 11 \\
& 880 & 4 & 2 & 3 \\
4.7 & & & & \\
& 900 & -5 & 110 & 51 \\
& 1800 & 10 & 68 & 39 \\
& 2700 & -11 & -46 & -28 \\
& 3600 & 40 & -19 & 10 \\
& 4500 & 57 & 31 & 44 \\
5 & & & & \\
& 900 & 17 & 120 & 69 \\
& 1800 & 63 & 220 & 140 \\
& 2700 & 84 & 290 & 190 \\
& 3600 & 26 & 190 & 110 \\
& 4500 & -19 & 110 & 44 \\
\hline
\end{tabular}

The average deviations in the mean PTB data relative to the mean NIST data for the 1 and $4.7 \mathrm{MN}$ force transducers and force steps examined are shown in Fig. 9. Because of the drift observed in the $5 \mathrm{MN}$ force transducer, the results obtained with this transducer were not included in the generation of Fig. 9. The average deviations fall within a band from -30 to $50 \mathrm{ppm}$. 


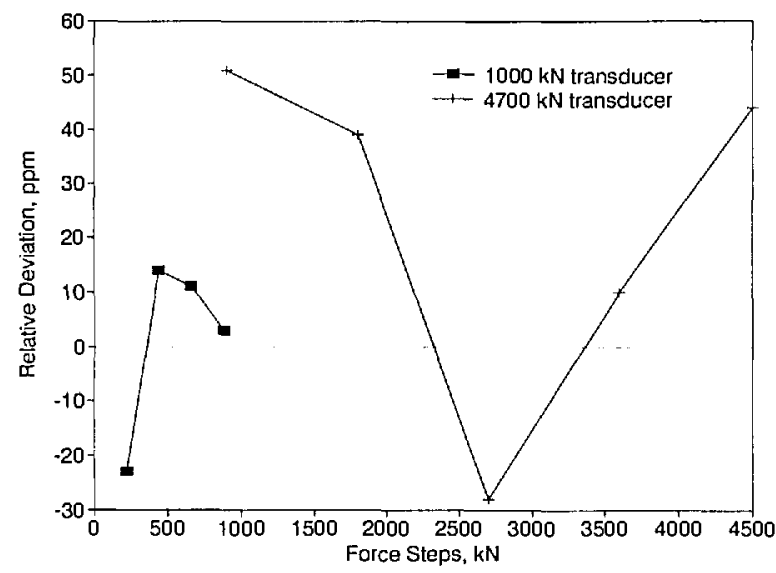

Figure 9. Deviations in the mean PTB data relative to the mean NIST data for the $220 \mathrm{kN}$ to $4.5 \mathrm{MN}$ range.

\section{Conclusions}

Over a range of 50 to $4500 \mathrm{kN}$, the forces realized in the NIST deadweight machines compare favorably with those realized at PTB. Comparison of forces up to $900 \mathrm{kN}$ indicate that the forces realized in the NIST deadweight machines and the forces realized in the PTB $1 \mathrm{MN}$ deadweight machines agree within $\pm 40 \mathrm{ppm}$. Peters et al. [7] have reported that theoretically the uncertainty in the forces realized by deadweight force machines is on the order of $\pm 20 \mathrm{ppm}$. Accordingly, for the 50 to $900 \mathrm{kN}$ force range, the agreement between the forces realized at NIST and PTB is close to what is theoretically achievable.

Comparison of forces in the range of 1 to $4.5 \mathrm{MN}$ indicate that the forces realized in the PTB hydraulic force multiplication system compare favorably with the forces realized in the NIST deadweight machines. In this range, the agreement between the PTB data and the NIST data is within $\pm 100 \mathrm{ppm}$, a remarkable agreement considering that the uncertainty of hydraulic force standard machine is inherently greater than that associated with deadweight machines.

\section{References}

[1] A. Sawla, M. Peters, S. L. Yaniv, and R. A. Mitchell, Intercomparison of Force Standard Machines of the National Institutc of Standards and Technology, USA, and the Physikalisch-Technische Bundesanstalt, Braunschweig, Germany, PTB-Bericht MA-20 (1991).

[2] R. A. Mitchell, Force Calibration at the National Bureau of Standards, NBS Technical Note 1227, U.S. Department of Commerce, Gaithersburg MD (1986).
[3] W. Weiler, M. Peters, H. Gassmann, H. Fricke, and W. Ackerschott, Die 1-MN-Kraft-NormalmeBeinrichtung der PTB Braunsehweig, VDI-Z, 120, 1-6 (1978).

[4] W. Weiler, A. Sawla, and M. Peters, Design and Calibration Problems of the 15 MN Hydraulic Force Standard Machine, VDI-Bericht 212 (1974).

[5] M. Peters and W. Wciler, Zur Kalibrierung der 15-MNKraft-NormalmeBeinrichtung der Physikalisch-Technischen bundesanstalt, PTB-Mitt 83 (1973).

[6] R. A. Mitchell and S. M. Baker, Characterizing the Creep Response of Load Cells, VDI-Berichte 312 (1978).

[7] M. Peters, A. Sawla, and D. Peschel, Uncertainty in Force Measurement, Report of the CCM Working Group Force, PTB-Bcricht MA-17 (1990).

[8] P. E. Pontius and R. A. Mitchell, Inherent Problems in Force Measurement, Exper. Mech. 22, 81-88 (1982).

About the authors: Simone L. Yaniv is a physical scientist in charge of the Force Group in the NIST Manufacturing Engineering Laboratory. M. Peters is in charge of the PTB Force Laboratory in Braunschweig, Germany where A. Sawla is a senior researcher. 